\title{
Application of 2d Electrical Resistivity Imaging for Mineral Ore Exploration Within a Basement Complex Formation
}

\author{
${ }^{*}$ G. O. Layade, ${ }^{2}$ C. O. Ogunkoya, ${ }^{3}$ V. Makinde and ${ }^{4 K}$.D. Ajayi \\ 1,3,4Department of Physics, Federal University of Agriculture Abeokuta, Nigeria \\ 2Department of Physics, Ajayi Crowther University, Oyo, Nigeria \\ [Corresponding Author: E-mail:layadeoluyinka018@gmail.com]
}

\begin{abstract}
A geophysical survey using electrical resistivity was carried out in Gbede community within latitude $\left(8^{\circ} 17^{\prime} 37.7^{\prime \prime} \mathrm{N}-8^{\circ} 17^{\prime} 49.8^{\prime \prime} \mathrm{N}\right)$ and longitude $\left(4^{\circ} 20^{\prime} 45.9^{\prime \prime} \mathrm{E}-4^{\circ} 20^{\prime} 58.8^{\prime \prime} \mathrm{E}\right)$ area of Oyo State southwestern Nigeria. The survey was to determine the location and the lateral extent of the suspected Iron Ore deposited in the area using $2 \mathrm{D}$ resistivity imaging.using a resistivity meter, Wenner array configuration and electrode spacing ranging from 5-25 m was implored in the survey. Five (5) electrical profiles each with $120 \mathrm{~m}$ long were conducted within the area. The RES2DINVsoftware was used on the data acquired for processing and inversion. The result of resistivity imaging revealed the lateral continuity of mineral ore deposit within the first layer(top soil) with resistivity values ranging from $395 \Omega \mathrm{m}$ to 6619 $\Omega \mathrm{m}$ at a mean depth of $13 \mathrm{~m}$. These values of resistivity suggest the presence of mineral ore in the form of magnetite and hematite which all constituted over $69 \%$ of iron in the study area.
\end{abstract}

Keywords: Imaging, Gbede, Wenner configuration, Iron ore, Pseudosection.

\section{INTRODUCTION}

Ore are rocks or minerals from which a valuable substance like metal can be extracted, some common ores include Iron Ore, Lead Ore, Copper, Mercury and Aluminum. The most common of the ore is Iron Ore made of magnetite and hematite which both contain about $70 \%$ of iron. Iron ore can be in the form of rocks or minerals from which metallic iron can be extracted for economical purpose (Gordon, 1996).

Furthermore, the most commonly used metal in the world is Iron because it is highly applicable in structural engineering, industries, automobiles and maritime purposes. According to Kato et al. (1969), over $90 \%$ of Iron ore is one of the raw materials used in producing steel. The highest percentage component of metal is regarded as (95\%) iron ore, these ores are usually rich in iron oxides and varying in colour from deep purple, bright yellow, dark grey, to rusty red, respectively. These according to Ramanaidou and Wells (2014) have been mined to produce almost every iron and steel materials used.
One of the geophysical prospecting techniques which can be used for the investigation of area of complex geology is electrical resistivity imaging (ERI) presented by Gomez-Ortez et al. (2006) which involves different measurement of profiling using computer control devices for the measurements between sets of selected electrode array.

ERI measures the apparent resistivity of subsurface materials through the injection of electric current between a pair of current electrodes and the measurement of potential difference between a pair of potential electrodes. The apparent resistivity measured can be processed to provide variations of resistivity with depth (Karim et al.2013).

Many works in the area of applied geophysics have employed the use of electrical resistivity imaging to investigate areas with moderately complex geology. According to Ganiyu et al. (2015) the subsurface was assumed to vary vertically down and laterally along the profile, but constant in the perpendicular direction. 
The 2D electrical resistivity survey to investigate Unilorin Dam for structural anomalies that may be in concession with the purpose and safety of the dam was applied by Raji and Adedoyin (2020). The result showed that the floor of the dam reservoir is comprises of weather basement rocks. Aizebeokhai et al. (2018) used four (4) traverses of 2D electrical resistivity imaging for delineating crystal basement and characterizing the subsurface in Ado-Ekiti. Furthermore, Nura et al. (2014) applied 2D electrical resistivity measurement to capture the outcome of pumping on seawater intrusion and upcoming. The result shows resistivity range between 1-10 ohmmeter for an upcoming and 10 to 25 ohmmeter for an intrusion of saline water from the sea. A research on environmental assessment of sewage disposal systems by Amidu and Olayinka (2006) was carried out using 2D electrical resistivity imaging and geochemical analysis. Their research shows low values of electrical resistivity located close to the septic tank while higher value is recorded farther away from the septic tank. Aizebeokhai et al. (2010) discussed $2 \mathrm{D}$ and $3 \mathrm{D}$ geoelectrical resistivity imaging for the investigation of a crystalline basement terrain and to ascertain the suitability of the area for ground water exploration. According to the work, spurious features from the 3D effects is often contained is in the image of $2 \mathrm{D}$ resistivity survey.

Ariyo et al. 2018 used electrical resistivity imaging to understand the suitability of a proposed site with Olabisi Onabanjo University campus for building construction. It was concluded that some of the proposed sites were structurally incompetent for engineering or foundation purposes and suggested that excavation of the topsoil is required to sustain the proposed structure. While Usifo et al. (2018), evaluated lateritic soil from Alapoti area in southwest using $2 \mathrm{D}$ electrical resistivity methods. The results from the 2-D inversed resistivity section showed the presence of lateritic clay, moderate laterite, and laterite sandy for second, third and fourth layer, respectively with resistivity ranging from 200 to $1,500 \Omega \mathrm{m}$. The resistivity value of rocks and minerals has no specific values but specific range. These values depend on geology and the structure of the minerals in each of the location. Some of the resistivity range according to Milsom (2003) is shown in Table 1

Table 1: Typical Resistivity values for some rocks and minerals

\begin{tabular}{ll}
\hline Rock/mineral & Resistivity $(\Omega \mathrm{m})$ \\
\hline Topsoil & $50-100$ \\
Loose sand & $500-5000$ \\
Gravel & $100-600$ \\
Clay & $1-100$ \\
Weathered bedrock & $100-1000$ \\
Sandstone & $200-8000$ \\
Limestone & $500-10000$ \\
Greenstone & $500-200000$ \\
Gabbro & $100-500000$ \\
Lateritic clay & $200-700$ \\
Lateritic sand & $1000-1500$ \\
Granite & $200-100000$ \\
Basalt & $200-100000$ \\
Kuarsite & $100-2500000$ \\
Graphitic schist & $10-500$ \\
Slates & $500-500000$ \\
Pyrite (ores) & $0.01-100$ \\
Phyrotite & $0.001-0.01$ \\
Chalcopyrite & $0.005-0.1$ \\
Galena & $0.001-100$ \\
Sphalerite & $1000-1000000$ \\
Magnetite & $0.01-1000$ \\
Cassiterite & $0.001-10000$ \\
Hematite & $0.01-1000000$ \\
\hline Source: Milsom, $(2003)$ \\
\hline
\end{tabular}

The main objective of the study is to use 2 dimensional resistivity model of the subsurface area of Gbede community to identify the suspected mineral ore through comparison of the resistivity with that of standard values (Table 1) and to determining the lateral and depth wise extension of the suspected mineral ore. 


\section{MATERIALS AND METHODS Location of the Study Area}

The study area (Gbede) is located in Surulere L.G.A of Oyo State, Southwest Nigeria. It is accessible through Ogbomoso - Gambari llorin road, and is about $30 \mathrm{~km}$ from llorin Airport. Gbedearea is located within latitude $8^{\circ} 17^{\prime} 37.7^{\prime \prime}$ and $8^{\circ} 17^{\prime} 49.8^{\prime \prime}$ North and between longitude $4^{\circ} 20^{\prime} 45.9^{\prime \prime}$ and $4^{\circ} 20^{\prime} 58.8^{\prime \prime}$ East (Figure 1). By visual inspection, the surface layer of most part of the study area is made up of residual deposit in the form of laterite. This posed a big challenge to the residents of the community in citing their artisanal well.

\section{Geology of the Study Area}

The Nigerian basement complex forms the Southern part of the Tran-Sahara Pan-African mobile belt of the Late Proterozoic (500 $750 \mathrm{Ma}$ ) age lying between the Achaean blocks of the West African craton bounded to the West and East by mobile belt(Caby 1989). It Comprises gneiss and migmatites with crustal relics which have yielded Archean (c. 2700Ma) and Proterozoic (c.2000Ma) ages (Annor, 1995; Dada et a. 1998). The rocks of the Precambrian crystalline complex of Nigeria were differentiated, by Oyawoye (1972) into four different groups, which include: The Ancient Metasediment, the Gneisses Migmatites, Older granites, and the Pegmatite and dolerite dykes, considered as a special minor group as shown in Figures 1.

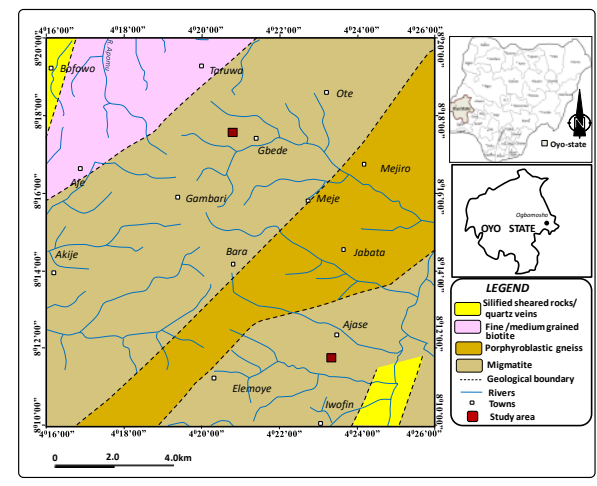

Figure 1: Location and Geology of the study area (adapted after Adegoke and Layade, 2019).

\section{RESEARCH METHODS}

The 2D-ERI investigation area was gridded into five electrical profiles (EP), each profile line fifty meters apart from the other and 120 meters in length. On each profile line, Wenner array was utilized to investigate the apparent resistivity variation of the subsurface. The Campus Tigre model resistivity meter with four electrodes, and four connecting wires of hundred meters each was used for the survey. The measurements of various resistivity data obtained were used to construct a pseudo section as well as contour in other to give a 2D image of the resistivity distribution within the sub-surface and then show a qualitative picture of the resistivity data obtained. An iterative smoothness-constrained least square inversion (ISLSI) were used to create a model for the subsurface resistivity of the calculated and inverted apparent resistivity data. However, RES2DINV (2010) package was used for the inversion and an acceptable model is normally arrived at within few iteration.

\section{DATA ANALYSIS}

The field data obtained for this research were resistance $(R)$, while the apparent resistivity values were determined by multiplying various geoelectric factor $\mathrm{K}$ with the resistance. For Wenner array the apparent resistivity is expressed as $\rho=K R$, and $K=2 \pi a$ where a is the electrode spacing. The calculated apparent resistivity value were later processed to create a $2 \mathrm{D}$ model for the subsurface imaging using RES2DINV software as represented in the results and discussion section.

\section{RESULTS AND DISCUSSION}

Electrical resistivity is routinely used for a wide range of applications, ranging from lithological variation, hydrology, environmental pollution to mineral exploration (Al Dulaymi et al. 2012; Fon et al., 2012; Teikeu et al., 2012). The qualitatively interpretation of the $2 \mathrm{D}$ resistivity models in geophysical terms is carried out in order to locate the presence of suspected mineral ore zone using electrical profiling as revealed by Ratnakumari et al. (2012). Based 


\section{Layade et al. Application of 2d Electrical Resistivity Imaging for Mineral Ore Exploration...}

on the electrical resistivity survey used to acquire information on the lateral variation of resistivity with depth, the result of the inversion process showed four geo-electric distinct layers delineated in the study site in consonant with the works by Adewoyin et al. (2017), Lawan et al. (2018) and Loke et al. (1996), respectively. The $2 \mathrm{D}$ inverse resistivity model presented in Figures 2-6 revealed varying shape of resistivity models at different depth due to nonhomogeneous nature of mineral ore within the study area (Abdullahi et al. 2018).

\section{Resistivity Profile 1}

The result of 2D ERI presented in profile 1 showed the presence of mineral ore in the form of hematite rock as shown in Figure 2 . However, not all of hematite rocks containing iron mineral occupies the profile due to discontinuous nature of iron mineralization (Octova and Yulhendra, 2017). Based on the resistivity values in Table 1 , the profile 1 is categorized into four layers. The first layer indicates resistivity greater than $2000 \Omega m$ which is suspected to be mineral ore in the form of hematite (Milsom, 2003), the horizontal distance from $7-90 \mathrm{~m}$ on the surface and average depth of $7.74 \mathrm{~m}$. The second and third layers depict lateritic sand $(800-2000 \Omega \mathrm{m})$ and lateritic clay $(100-800 \Omega \mathrm{m})$ respectively. This is followed by the last layer having low resistivity anomaly $(30-100 \Omega \mathrm{m})$ at a horizontal distance from $25.0 \mathrm{~m}$ to $127.0 \mathrm{~m}$. The noticed feature based on the resistivity value is the dominance of clay in the basement with depth ranging from $8.59 \mathrm{~m}$ to $14.4 \mathrm{~m}$.

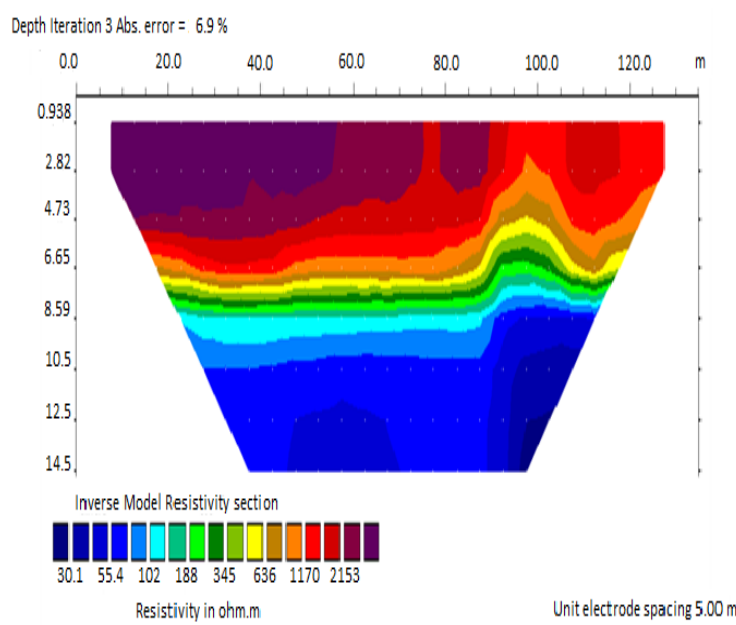

Figure 2: 2D Inverse model resistivity section for profile 1

\section{Profile 2}

The basic concept of resistivity method is to demarcate higher resistivity layers within the lower electrical resistivity materials at the sub surface (Srinivasamoorthy et al., 2009).The pseudo section obtained in Figure 3 highlights two mineral layers as evidence of mineral zone occurrence in profile 2 . The first layer is located at lateral distance $20.0-33.0 \mathrm{~m}, 55.0-64.0 \mathrm{~m}$, and $66.0-115.0 \mathrm{~m}$ close to the surface of the ground prospected. Based on the resistivity range of rocks and minerals in Table 1 by Milsom (2003), this layer indicates the presence of hematite with resistivity exceeds $2500 \Omega \mathrm{m}$ and 0.94-10.2 $\mathrm{m}$ deep. The second layer at a depth of $0.94-14.5 \mathrm{~m}$ represents magnetite with resistivity value between $1000-2500 \Omega \mathrm{m}$ located at lateral distance $7.0-14.0 \mathrm{~m}$ and 18.0 $116.0 \mathrm{~m}$. The third layer at distance 14.0-45.0 $\mathrm{m}$ and $65.0-127.0 \mathrm{~m}$ depicts lateritic clay at depth between 0.94-14.5 m. While the fourth layer shows the lowest resistivity in the profile indicating the presence of clay material. 


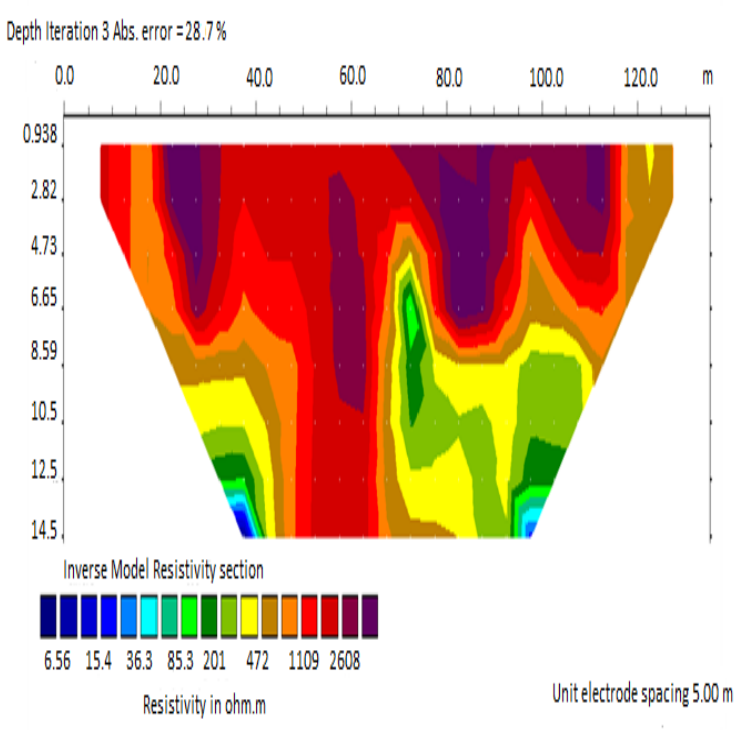

Figure 3: 2D Inversion model resistivity section of profile 2

\section{Profile 3}

The 2D section of the profile 3 in Figure 4 shows a heterogeneous subsurface geological structure with four layers as posited by Lawan et al.(2018). The profile indicates the presence of mineral ore in the form of hematite $(>3000$ $\Omega \mathrm{m})$ with an approximate depth of $2.0 \mathrm{~m}$ at lateral distance $55-75 \mathrm{~m}$. The second layer also revealed an isolated high resistivity zone with different depth due to the worked activity of the near surface materials (Christiansen and Auken, 2004). This layer has horizontal distance of $50-80 \mathrm{~m}, 23-35 \mathrm{~m}$ and depth from $0.94-4.70 \mathrm{~m}$ from the surface. The resistivity values between 1000-3000 $\Omega \mathrm{m}$ are an indication of magnetite. The third layer is a low resistivityzone (200-1000 $\Omega \mathrm{m})$ suspected to be lateritic soil were noticed at lateral distance 7$127 \mathrm{~m}$ with depth 0.94-14.5 $\mathrm{m}$ while the last layer is suspected to be lateritic clay with resistivity from $70-200 \Omega m$.

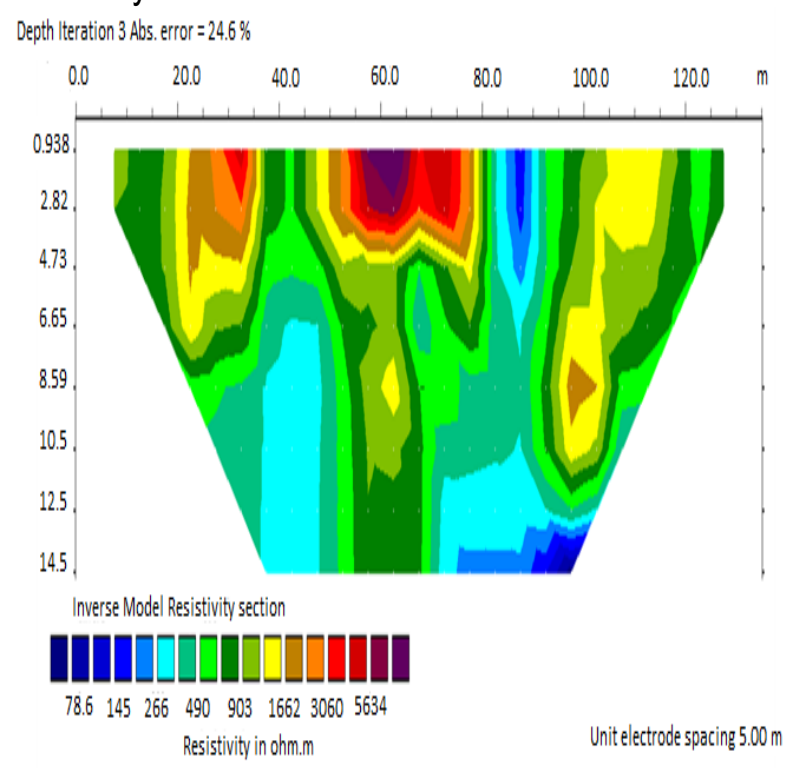

Figure 4: 2D Inversion model resistivity section for profile 3

\section{Profile 4}

Figure 5 reveals four layers in an inverse model section for profile 4 and shows variation in resistivity along the profile line with depth (Usifo et al., 2018). This profile captured high resistivity material interpreted to be magnetite and hematite. The first and second layer is characterized with continuous spread of high resistivity value of $1000-3000 \Omega \mathrm{m}$ and 3000 $\Omega \mathrm{m}$. It spread through 7.0-26.0 m, 40.0-51.0 m with depth between 0.94-4.95 $\mathrm{m}$ for hematite and through 7.0-78.0 $\mathrm{m}$ at depth from 0.94-7.40 $\mathrm{m}$ for magnetite. The third and fourth layers of the profile depict low resistivity material interpreted to be lateritic sand and lateritic clay as revealed by Barker et al. (1992) and Keary et al., (2002) with resistivity 200-1000 $\Omega \mathrm{m}$ and 90-200 $\Omega \mathrm{m}$, respectively. 


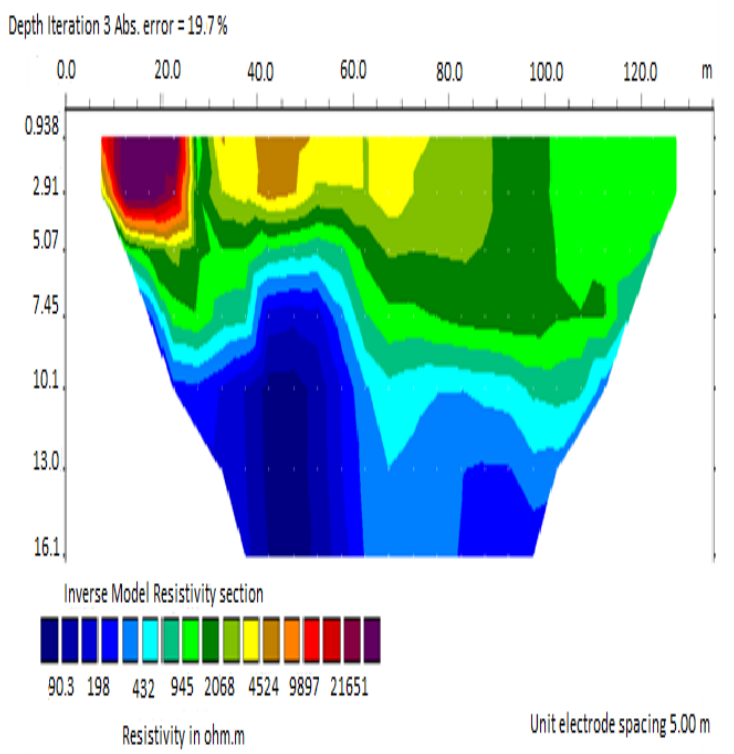

Figure 5: 2D Inversion model resistivity section of Gbede profile 4

\section{Profile 5}

Electrical imaging provides us with more detailed information on the location of the mineralized zone (Dakir et al., 2019). The result of the resistivity model for profile 5 as presented in Figure 6 revealed the the presence of two mineralized layers among the four layers of the profile in Table 2. The first layer is located at the lateral distance 15.0-65.0 $\mathrm{m}$ (at a depth 0.94-2.95 m). The resistivity exceeds $2128 \Omega \mathrm{m}$ which was suspected to be hematite. The second layer is close to the end of the profile (at the lateral distance 7-78 $\mathrm{m}$ and 90-95 m). Its resistivity value is $1000-2150 \Omega \mathrm{m}$ and suspected to be magnetite according to Milsom (2003) with $5.3 \mathrm{~m}$ deep. The third layer depicts lateritic sand because its resistivity range is 200-1000 $\Omega \mathrm{m}$ at lateral distance from 15-120 m as it is underlain by lateritic clay of resistivity range between 30 and $200 \Omega \mathrm{m}$ (Adekunle et al., 2014; Usifo et al., 2018).

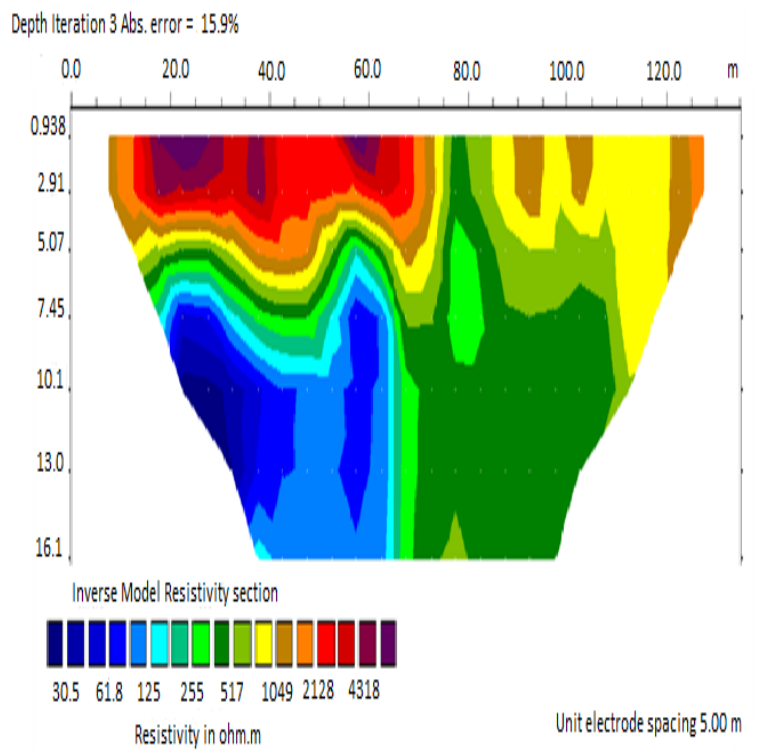

Figure 6: 2D Inversion model resistivity section for Gbede profile 5

\section{CONCLUSION}

The geo-electrical resistivity method with 2dimensional electrical profiling used in this research as provided a representation of mineral ore in the subsurface of the study site. The inversion results application of $2 \mathrm{D}$ electrical resistivity using the RES2DINV software revealed four different layers under the study. It is seen from the model produced that magnetite and hematite were the two mineral ore identified at depth range between 2.85 and 16.1 $\mathrm{m}$ from the surface with their resistivity value greater than $2000 \Omega \mathrm{m}$. It is therefore concluded that $2 \mathrm{D}$ electrical resistivity method can provide image of the suspected mineral ore in the subsurface using the RES2DINV software while other geophysical method can further be applied in the area for corroboration. 
Table 2: Interpretation of vertical electrical sounding data showing lithological characteristics of the study area

\begin{tabular}{|c|c|c|c|c|c|}
\hline PROFILES & LAYERS & $\begin{array}{l}\text { RESISTIVITY } \\
\text { VALUE }\end{array}$ & $\begin{array}{l}\text { LATERAL } \\
\text { DISTANCE }\end{array}$ & $\begin{array}{l}\text { DEPTH TO THE } \\
\text { MINERAL }\end{array}$ & LITHOLOGY \\
\hline \multirow[t]{4}{*}{1} & 1 & $>2000$ & $7-90$ & $0.94-4.8$ & Hematite \\
\hline & 2 & $800-2000$ & $18-125$ & $0.94-6.7$ & Lateritic sand \\
\hline & 3 & $100-800$ & $20-120$ & $2.8-8.59$ & Lateritic clay \\
\hline & 4 & $30-100$ & $25-127$ & $8.60-14.5$ & Clay \\
\hline \multirow[t]{4}{*}{2} & 1 & $>2500$ & $\begin{array}{l}20-33, \quad 55-64, \quad 66- \\
115\end{array}$ & $0.94-10.2$ & Hematite \\
\hline & 2 & $1000-2500$ & $7-14,18-116$ & $0.94-14.5$ & Magnetite \\
\hline & 3 & $200-900$ & $14-45,65-127$ & $0.94-14.5$ & Lateritic clay \\
\hline & 4 & $6.0-90$ & $30-40,95-105$ & $13.5-14.5$ & Clay \\
\hline \multirow[t]{4}{*}{3} & 1 & $>3000$ & $55-75$ & $0.94-2.85$ & Hematite \\
\hline & 2 & $1000-3000$ & $50-80,23-35$ & $0.94-4.70$ & Magnetite \\
\hline & 3 & $200-1000$ & $7.0-12.7$ & $0.94-14.5$ & Lateritic sand \\
\hline & 4 & $70-200$ & $75-105$ & $0.94-4.70,12.6-14.5$ & Lateritic clay \\
\hline \multirow[t]{4}{*}{4} & 1 & $>3500$ & $7.0-26,40.0-51$ & $0.94-4.95$ & Hematite \\
\hline & 2 & $1000-3500$ & $7.0-78$ & $0.94-7.40$ & Magnetite \\
\hline & 3 & $200-1000$ & $10-127$ & $0.94-16.1$ & Lateritic sand \\
\hline & 4 & $90-200$ & $12-118$ & $7.45-16.1$ & Lateritic clay \\
\hline \multirow[t]{4}{*}{5} & 1 & $>2128$ & $15.0-65.0$ & $0.94-2.95$ & Hematite \\
\hline & 2 & $1000-2150$ & $\begin{array}{l}7.0-78, \quad 90.0-95.0 \\
100.0-107, \quad 120.0- \\
127.0\end{array}$ & $0.94-5.30$ & Magnetite \\
\hline & 3 & $200-1000$ & $15.0-120.0$ & $0.94-16.1$ & Lateritic clay \\
\hline & 4 & $30-200$ & $18.0-64$ & $5.2-16.1$ & Clay \\
\hline
\end{tabular}

\section{REFERENCES}

Abdullahi, N. K., Ahmad, M.S., \& Abubakar, A. (2018). Application of electrical resistivity tomography technique for delineation of gold mineralization in Bugai town, BirninGwari, Kaduna, Northwestern Nigeria. Environmental and Earth Sciences Research Journal, 5(1):29-35.

Adegoke, J. A., \& Layade, G. O. (2019). Comparative depth estimation of ironore deposit using the Data-Coordinate Interpolation Technique for airborne and ground magnetic survey variation, African Journal of Science, Technology, Innovation and Development,11(5): 663-669.
Adekunle, A., Ekandem, E. S., Ibe, K. E., Ananso, G. N., \& Mondigha, E. B., (2014). Analysis of thermal and electrical properties of laterite, clay and sand samples and their effects on inhabited buildings in Ota, Ogun State, Nigeria. Journal of Sustainable Development Studies, 6(2): 391 - 41.

Adewoyin O. O., Joshua E. O., Akinyemi M. L., Omeje $M$ and Joel E.S (2017). Application of 2D electrical resistivity imaging and cone penetration test to assess harzardous effect of near surface water on foundations in Lagos Nigeria, Journal of Physics-Conference series, (1) 852.

Aizebeokhai, A.P., Oyeyem K.D., Ogungbade O. (2018) Geoelectrical resistivity data set for characterising crystalline 
basement aquifers in Basiri, Ado-Ekiti, southwestern Nigeria. Data in Brief, 19:810-816.

Aizebeokhai, A.P., Olayinka, A.I., \& Singh, V.S. (2010). Application of 2D and 3D

Geoelectricalresistivity imaging for engineering site investigation in a crystalline basement terrain, Southwestern Nigeria. Journal of Environment and Earth Sciences, 61(7):1481-1492.

Al Dulaymi, A. S., Al-Heety, E. A. R. \& Hussien, B. M. (2012). "Geo-Electrical Investigation of Mullusi Aquifer, Rutba, Iraq." International Journal of Geosciences, 3(3): 549-564.

Amidu, S.A., \& Olayinka, A.I. (2006). Environmental assessment of sewage disposal systems using 2D electrical resistivity imaging and geochemical analysis: A case study from Ibadan, Southwestern Nigeria. Environmental Engineering Geosciences,12(3), 261272 ..

Annor, A. E. (1995). U-Pb zircon age for KabbaOkenegranodiorite gneiss: implications for Nigeria's basement chronology. Africa Geoscience Review, 2:101-105.

Ariyo, S. O., Fatoba J.O., Bayewu O. O., Omosanya K.O., \& Lawal M.A. (2018). Geophysical assessment of subsurface conditions at proposed building sites: implications for foundation failure and building collapse. GeoScience Engineering, 64(3): 8-20.

Barker, R. D., White, C. C. \& Houston, J. F. T.(1992). Borehole siting in an African accelerated drought relief project In: $E$. P. Wight and W. G. Burgess, (eds). The hydrogeology of crystalline basement aquifers in Africa. Geological Society Special Publication, 66(1):183 $-20$

Caby, R. (1989). Precambrian terranes of the Benin-Niger and Northeast Brazil and the LateProterozoic South Atlantic fit. Geological Society of America Special Paper, 230(1):145-158.
Christiansen, A.V., \& Auken, E. (2004). Optimizing a layered and laterally constrained 2D inversion of resistivity data using Broyden's update and 1D derivatives. Journal of Applied Geophysics, 56(4): 247-262.

Dada, S. S., Briqueu, L., \& Birck, J. L. (1998). Primordial crustal growth in northern Nigeria: Preliminary $\mathrm{Rb}-\mathrm{Sr}$ and $\mathrm{Sm}-\mathrm{Nd}$ constraints from Kaduna migmatitegneiss complex. Journal of Mining and Geology, 34(1): 1-6.

Dakir, I., Benamara, A., Aassoumi, H., Ouallali, A., \& Bahammou, Y.A. (2019). Application of Induced Polarization and Resistivity to the Determination of the Location of Metalliferous Veins in the Taroucht and Tabesbaste Areas (Eastern Anti-Atlas, Morocco). International Journal of Geophysics, 2019:1-11.

Fon, A. N., Che, V. B., \& Suh, C. E. (2012). Application of Electrical Resistivity and Chargeability Data on a GIS Platform in Delineating Auriferous Structures in a Deeply Weathered Lateritic Terrain, Eastern Cameroon.International Journal of Geosciences. 3: 960-971

Ganiyu, S. A., Badmus B. S., Oladunjoye M. A., Aizebeokhai A. P., \& Olurin O. T. (2015). Delineation of Leachate Plume Migration Using Electrical Resistivity Imaging on Lapite Dumpsite in Ibadan, Southwestern Nigeria. Geosciences, 5(2): 70-80.

Gomez-Ortiz, D.S., Marton-Velazquez, T., Martin-Crespo, A., Morquez, J., Lillo, I., Lopez, F., Carrego, F., Martin-Gonzolez, R.,\& Herrera, M.A. (2006). Joint application of ground penetrating radar and electrical resistivity imaging to investigate volcanic materials and structures in Tenerife (Canary Islands, Spain). Journal of Applied Geophysics, 62(3): 287-300.

Gordon, R.B. (1996). American Iron 16071900.The Johns Hopkins University 
Press.Karim, H.H., Alwan, I.A.K., \& AlNeami, M.A., (2013).Characteristics of 2D-electrical resistivity imaging survey for soil. Engineering \&Technical Journal, 31(19): 70-89.

Kato, M. and Minowa, S. (1969). Viscosity Measurement of Molten Slag-

Properties of Slag at Elevated Temperature (Part 1).Transactions of the Iron and Steel Institute of Japan, Tokyo.Nihon Tekko Kyokai, 9(1), 3138.

Kearey, P., Brook, M., \& Hills, I. (2002). An introduction to geophysical exploration, 3rded. Blackwell science.

Nura, N.U., Ramli, M.F., Ibrahim, S., Sulaimon, W. N., Zaudi, M.A., \& Aris, A. Z. (2014). A preliminary appraisal of the effect of pumping on seawater intruision and upcoming in a small tropical Island using 2D resistivity technique. The Scientific World Journal.2014:1-11.

Lawan, A.M., Raimi, J., \& Ahmed A.I. (2018). Characterization of the iron ore deposit using $2 \mathrm{D}$ resistivity imaging and induced polarization technique at Diddaye-Potiskum area, Northeastern Nigeria. Physical Science \& Biophysics Journal, 2(1): 1-12

Loke, M.H. \& Barker, R.D. (1996). Practical techniques for 3D resistivity surveys anddata inversion. Geophysical Prospecting, 44(3): 499-524.

Milsom, J. (2003). Field Geophysics. John Willey \& Sons Ltd. England. ISBN: 0470-84347-0. p88

Oyawoye, M. N. (1972). The basement complex of Nigeria, in African Geology. University of Ibadan press.

Octova, A. \&Yulhendra, D. (2017). Iron ore deposits model using geo-electrical resistivity method with dipole-dipole array![Paper presentation]. MATEC Web of Conferences, Bangka Island, Indonesia.

Raji W.O \& Adedoyin A.D (2020): Dam safety assessment using 2D electrical resistivity geophysical survey and geological mapping. Journal of King Saud University Science, 32(1): 11231129

Ramanaidou, E. R. \& Wells, M. A. (2014). Sedimentary Hosted Iron Ores: Geochemistry of sedimentary iron ore (2nd edition). Elsevier.

Ratnakumari, Y., Rai, S. N., Thiagarajan, S. and Kumar, D., (2012). 2D Electrical resistivity imaging for delineation of deeper aquifers in a part of the Chandrabhaga river basin, Nagpur District, Maharashtra, India. Current Science, 102(1):61-69.

Srinivasamoorthy, K., Sarma, V. S., Vasantavigar, M., Vijayaraghavan, K., Chidambaram, S., \& Rajivganthi, R. (2009). Electrical imaging techniques for groundwater pollution studies: a case study from tamilnadu state, south india. Earth sciences research journal, 13(1): 30-39.

Teikeu, W. A., Ndougsa-Mbarga, T.,Njandjock, P. N., \&Tabod, T. C. (2012). Geoelectric Investigation for Groundwater Exploration in Yaounde Area, Cameroon. International Journal of Geosciences, 3(3): 640-649.

Usifo, A. G., Adewole, J. A., Akinnawo, O. O., \&Onaiwu, K. N. (2018). Evaluation of Lateritic soil using 2-D electrical resistivity methods at Alapoti, Southwestern Nigeria. Global Journal of Pure and Applied Sciences, 24(1), 25-36. 